\title{
FAITH AND DISASTER RESILIENCE: WHAT CAN ISLAMIC EDUCATION TEACH CHILDREN TO HELP PREPARE THEM FOR A DISASTER?
}

\author{
Maila Dinia Husni Rahiem \\ Syarif Hidayatullah State Islamic University of Jakarta, Indonesia \\ E-mail: mailadinia@uinjkt.ac.id
}

\author{
Received: $10^{\text {th }}$ August 2018; Revised: $25^{\text {th }}$ November 2018; Accepted: $28^{\text {th }}$ December 2018
}

\begin{abstract}
Children used their internal mechanisms, including faith, in coping and bouncing back after a disaster. In this paper, researcher examines the role of faith in building more resilient communities, and also how Islamic education at school can be used to help teach children to be better prepared for a disaster. The research suggests that Islamic education could be used to increase students hope after a disaster, to seek prayer as a source of strength and peace, to see the essential role of Muslim clergies in disaster recovery, and to see how some religious practices need to be understood in better ways. Qualitative narrative research was used as the method of inquiry with the primary source of data coming from interviews. There are 27 child survivors being interviewed. All those interviews were audio-recorded and transcribed, then the transcripts were analysed to find any emerging themes.
\end{abstract}

Keywords: resilience; children; Aceh; tsunami; disaster; Islamic education

\section{Abstrak}

Beberapa anak menggunakan mekanisme internal mereka, termasuk iman, dalam mengatasi dan bangkit kembali setelah bencana. Dalam makalah ini, peneliti meneliti peran iman dalam membangun komunitas yang lebih tangguh, dan juga bagaimana pendidikan Islam di sekolah dapat digunakan untuk membantu mengajar anak-anak agar lebih siap menghadapi bencana. Penelitian ini menunjukkan bahwa pendidikan Islam dapat digunakan untuk meningkatkan harapan pelajar setelah bencana, untuk menjadikan doa sebagai sumber kekuatan dan perdamaian, untuk melihat peran penting para ulama Muslim dalam pemulihan bencana, dan untuk melihat bagaimana beberapa praktik keagamaan perlu dilakukan. dipahami dengan cara yang lebih baik. Penelitian naratif kualitatif digunakan sebagai metode penyelidikan dengan sumber data utama yang berasal dari wawancara. Ada 27 anak yang selamat yang diwawancarai. Semua wawancara itu direkam dan ditranskripsi, kemudian transkrip dianalisis untuk menemukan topik yang tampak.

Kata kunci: ketahanan; anak-anak; Aceh; tsunami; bencana; pendidikan Islam

How to Cite : Rahiem, M. D. H. (2018). Faith and Disaster Resilience: What can Islamic Education Teach Children to Help Prepare Them for a Disaster?. TARBIYA: Journal of Education in Muslim Society, 5(2), 178-192. doi:10.15408/tjems.v5i2.9964.

Permalink/DOI: http://dx.doi.org/10.15408/tjems.v5i2.9964 


\section{Introduction}

The 2004 Aceh tsunami is one of the most destructive disasters in history. It started with a massive undersea earthquake with a magnitude of 9.1, which struck off the northern coast of Sumatra and was then followed by a series of tsunamis; it is reported in some locations that the waves had reached a height of nine meters or more when they first hit the shoreline; the catastrophe killed at least 225,000 people in several countries, with Indonesia sustaining the most damage, as the death toll there alone exceeded 200,000 (The Encyclopedia of Britannica, 2006). The highest number of tsunami victims in Aceh was reportedly children, but the exact number was not actually ever recorded.

When disaster happens, children are at the highest risk of being affected by the negative effects of it (Peek, 2008). Children are vulnerable to post-traumatic stress disorder and other symptoms; they are also vulnerable to physical injury, illness, abuse and death; and their education could also be disrupted (ibid). Counting the effects of disasters does not only involve the number of deaths or the economic loss, it has longer and far reaching effects upon children, including: it influences the growth and development of children, reduction in school attendance and social events, decrease in the academic achievement of children, while also increasing the exposure to life's stresses like family illness, divorce, violence, and substance abuse (Silverman and La Grecca, 2002). Disasters like floods, drought, earthquakes, and landslides, are the main cause of disease and death for children, both directly and indirectly (Dyregrov, Yule, and Olff, 2018).

Briggs (2017) predicted that one in four school-age children around the world, or nearly 500 million children, live in countries experiencing humanitarian crises like natural disasters, disease outbreaks and conflicts; it is estimated around 75 million children are disrupted from their education, receiving low quality schooling and are even at risk of dropping out from school. Nowadays, we are also facing disasters caused by climate change. Approximately 17 million children every year are affected by a natural disaster caused by climate change (Codreanu, Celenza, and Jacobs, 2014). There is no factual data on how many children are injured or die from disasters caused by climate change, but the number is high, they experience post-traumatic stress disorder (PTSD), depression, anxiety and other mental health problems (Kar, 2009). Globally, it is estimated that climate change accounts for 88 percent of diseases in children, while the poorer they are the possibilities are even higher (Philipsborn and Chan, 2018).

After disasters, some children have generally mild and moderate psychological reactions, while unfortunately there are some who develop fullblown and debilitating symptoms of PTSD (Silverman and La Grecca, 2002). There is various research on children's psychological reactions to disasters: the different reactions of children and adolescents toward disasters (Vogel and Vernberg, 1993); phases of time periods on children's reactions to disaster from the period before the disaster (pre-impact), when the disaster happens (impact), immediately after disaster (recoil), days to weeks after disaster (post-impact) and the recovery that happens months or years after the event; children's immediate reactions to disaster are often that they sense strangeness and that life is weird or different (Coffman, 1994); children are mostly clinically diagnosed to have adjustment disorder and acute stress disorder in the post-impact phase (Silverman and La Grecca, 2002); children might experience PTSD in the recovery phase, with symptoms of re-experiencing, like dreaming or intrusive thoughts of the event, avoidance or a 
numbing like decreasing interest in their usual activities and a feeling of detachment from others, and hyperarousal leading to difficulties sleeping, concentrating and becoming easily irritated or angry.

However, there is little research on the factors that contribute to children's reactions to disasters. On researcher's previous research conducted with two other researchers on disasters, "Religious Interpretations and Psychological Recovery from the Aceh 2004 Tsunami," has shown that religion and culture have a significant impact on psycho-emotional reactions and recovery. The research tried to understand how the victims of the Aceh tsunami perceived disasters, death and loss because of disasters, and how they then used their faith to recover. In that research, the adult survivors of the Aceh tsunami were interviewed. The data then analysed using a thematic analysis, with the themes that appeared then explained through the lens of three Muslim scholars and their responses then related to Islamic perspectives on disasters. The research found five specific views: the disaster was preordained from God; there will be ease after the hardship; one must be grateful for what they still have; to pray to and remember God to find peace; and those who died are martyrs and were rewarded by God with life in heaven (Rahiem, Abdullah, and Krauss, 2017). The research suggested post-disaster mental health programs need to respect the perspectives of the victims, involve religious figures, incorporate religious practices such as praying as a way of coping and healing, and incorporate mental health programs with livelihood programs that provide opportunities to victims to rebuild their lives.

Following that, researcher conducted further research with two other researchers entitled, "Stories of Resilience: Survival, Coping and Thriving among Children on the Aceh Tsunami." This research tried to understand how child survivors of the 2004 Aceh tsunami survived the tsunami itself, coped with the aftermath, and then progressed with their lives after that. Twenty-seven child survivors, who were either teenagers or young adults aged between 17 to 24 years old, were interviewed. They had lost one or both of their parents. The research revealed that in the immediate aftermath of the tsunami, child survivors feel the need to have someone to talk to and share their feelings; they still feel the sadness, horror, and trauma of tsunami, but they often keep it to themselves; they accept the tragedy as their destiny from God; some of them are very optimistic about their own future and some are not; how the young survivors coped with the immediate aftermath of the tsunami depended upon the support received from their family and communities, combined with their own inner strength and will to survive; a personal resilience formed from these internal and external sources, both in the short and long term (Rahiem, Krauss, and Rahim, 2018).

In this paper, one of the findings is discussed, "They accept the tragedy as their destiny from God." This finding shows the strong faith of the child survivors connected to their religious teaching. They have used their faith as a source of coping, healing, and thriving.

Islamic education is a compulsory subject in schools in Indonesia, from kindergarten level to higher education level. The formal early childhood education curriculum structure contains the development of religious and moral values, cognitive, language, social, emotional, and artistic motoric. Most early childhood education is private, and faith based, with only 3.207 registered as public kindergartens out of a total of 85.174 kindergartens (PDSPK Kemendikbud Statistik Pendidikan Anak Usia Dini, 2017). Most of the private kindergartens are communal and/or organizations affiliated to religion. Therefore, most kindergartens are 
Islamic kindergartens and all the lessons are following Islamic values and teaching (Rahim and Rahiem, 2012). Islamic education in elementary, middle and high school, is increased in frequency with two lessons per week at kindergarten level to four hours in elementary school and then three hours in middle and high school. In Islamic schools, the portion of Islamic education ranges from 30 percent up to 100 percent depending upon the type of school (Rahim, 2001). Of the participants interviewed, some were studying in public elementary Islamic schools, but they also joined Islamic education and Quranic reading courses after school hours. There were also some subjects who studied in Islamic schools.

Islamic religious education is a systematic and pragmatic effort to help students live according to the teachings of Islam (Zuhairani, 1983; Tafsir, 2005). It is an effort to actualize the qualities of perfection that have been granted by Allah to mankind; these efforts are carried out without any interest except for merely worshipping Allah (Bawani, 1993). Islamic education is a process of delivering information in the framework of the formation of a faithful and fearful human being, so that man is aware of his position, duties, and functions in the world by always maintaining his relationship with God, himself, society, and the surrounding world, as well as his responsibility to God (including himself and his environment) (Ali, 1995).

Islamic education is not only theoretical, but also practical. Islamic teachings do not separate faith and deeds. Therefore, Islamic education is a faith education and an education of how to do good deeds; Islamic teachings contain the teachings of personal attitudes and behaviour towards individuals and shared welfare, so Islamic education includes individual education and community education. Initially, the task of educating was the subsequent Prophets and Apostles of the scholars, and scientists as the successors of their duties, and obligations (Drajat, 1992: 25-28).

Islamic education needs to teach about everyday life, facing the threat and challenges of life, including disaster preparedness, rescue, and recovery. The previous research explained how the adult survivors and Muslim scholars viewed the disasters as having lots of influence from their faith. As agreed by the adults in the previous research, child survivors interviewed in the research also explained that they had utilized their faith as a source of strength to bounce back after the catastrophe. This paper highlights how religious faith helped the child survivors to cope and bounce back, and this will enable suggestions to be made concerning what schools could teach in Islamic education lessons, related to disaster, in order to prepare the students in the event of a disaster and to be able to use their faith to be resilient, based on the previous experience of the child survivors of the Aceh tsunami.

"Resilience is the process of adapting well in the face of adversity, trauma, tragedy, threats or even significant sources of stress (The American Psychological Association, 2014, para. 4). While Psychology today defined it as "the ineffable quality that allows some people to be knocked down by life and come back stronger than ever. Rather than letting failure overcome them and drain their resolve, they find a way to rise from the ashes" (Psychology Today, 2018). The definition of resilience questions: is resilience a trait, a process, or a result? Resilience is a growing process, a continuum that is present in various domains of human life (Southwick et al, 2014).

\section{Method}

Narrative inquiry was applied in capturing and analyzing human experiences as a phenomenon under study in the form of 
narratives (Conelly and Clandinin, 2006). In narrative inquiry, researchers explore not only individual narratives, but also social, cultural, and institutional ones (Lessard, Caine, and Clandinin, 2015). Narrative inquiry used to capture and analyze the experiences of 27 child survivors of 2004 Aceh tsunami. They had lost at least one parent and were aged 6-12 years old at the time of the disaster. They were however between the ages of 17 to 24 years old at the time of the interviews. They were from two villages in the district of Banda Aceh and four villages in the district of Aceh Besar. The participants were interviewed in-depth and asked to share their prior experiences of living through the tsunami. The questions focused on: how they coped and how their lives were now at the time of the interview. Besides interviewing, a reflexive journal was also used. Reflexive journals are used to write memos on noticeable issues that emerge from interviews and debriefing (Fontana and Frey, 2003). All those interviews were audiorecorded and then transcribed. Some parts of the interviews, or statements of the participants, are used as quotes in the findings. Those quotes were translated using vernacular English by a native speaker. To ensure validity, member checks were completed by asking the study participants to check and edit the content of the transcripts. In analyzing the data, each of data analyzed separately and then together in order to capture as full an analysis as possible (Mafile'o and Kaise Api, 2009). The transcripts were analyzed to find any emerging themes from the stories told, the themes were not set at the beginning of the study, like in quantitative studies (McCracken, 1988 cited in Atkinson, 1998: 59).

This paper focuses on one specific finding, which concerns how religious faith helped these children to both cope and thrive. These children were at elementary school age at the time of the tsunami. During interviews they mentioned how religious teachings had helped them to cope and become resilient. They mentioned how their belief in God, life after death, and the belief that those who died were martyrs had given them the hope and spirit to continue with their lives. They mentioned that they learned this faith from home and also from school. Then, we followed their statement by asking what exactly school had taught them about it. This research and more specifically what is written in this paper is useful to inform teachers, researchers, schools, and policy makers in Islamic education about what lessons have been learned from the 2004 tsunami child survivors learnt about Islamic teaching and the values that they learnt from school that helped them to negotiate the hard times in the aftermath of the disaster. This is also to inform those who work with children in Muslim communities during and after a disaster, to help them understand their values and perspectives on disasters and what internal and external strength they have. This could be suggestions for better teachings of religious lessons that highlight the personal human ability, interpersonal reaction and interaction, and their connection to God.

\section{Results and Discussion}

Some previous studies have shown that faith is a source of resilience; after a disaster, survivors try to understand the event-how the world works and make adjustments using their own experiences and interpretation, which is shaped by their cultural background and religious beliefs (Rahiem et al., 2017). Beneficiaries cope in a way that highlights how religious people maintain their wellbeing when facing adversity (Safdar, 2009). Their social, economic, and political background affects the way they respond to the disaster (Wisner, 2004).

This research found that the perspectives of the child survivors of the 2004 Aceh tsunami 
about the disaster, are highly affected by their faith, as the following points highlight: religious faith kept them staying positive and full of hope; praying is a dialogue and the source of peace and strength; the religious leaders/clerics have significant roles in the recovery process; women need to be empowered regarding how they need to survive in an emergency situation.

In this part we also discuss, how these faithbased perspectives would benefit the community, especially children, to cope and thrive when they learn about them in Islamic education lessons at school.

\section{Religious Faith Kept the Victims Positive and Full of Hope}

The child survivors see the tragedy as God's test and they accepted it without anger. A and B, who now live alone, lost both their parents and their siblings in the tsunami and accepted it as their destiny. B emphasized that they were not mad at god, "God tested us, we should not get mad at God." (B/Interview). A said, "This is God's test. We accept it." (A/Interview).

C, who lost both parents, two sisters, one brother, and only survived with her older teenage brother, explained that although it is human to have these feelings of anger, she prevents this feeling of anger from emerging.

She believes that any tests from God, which are given to humans, have wisdom behind them, because God knows the best for every being; humans need to accept his/her destiny; God's test(s) will make people more resilient. "I just thought, there is only God. So, what happens to us, God rules this all. So, why should we complain? That is a waste. It makes us more sinful, after all, isn't it bad, to hate something?" (C/Interview).

$\mathrm{D}$, who was just nine years old at the time of tsunami, lost both parents and all of his siblings and was raised by his grandfather after the tsunami. Despite his sad childhood, D stated, "I have never been mad to God, I haven't even considered being angry. This is the best for my family and me. I pray for them every day. So, that all of my family will be saved in life and the afterlife." (D/Interview).

Rahiem et al. (2017) also discovered that this refusal to blame God, was one of the perspectives of the adult survivors of the Aceh tsunami, in that God will not give tests or obstacles more than what we can actually bare and that $\mathrm{He}$ promises there will always be ease after the hardship. Humans cannot simply run from their troubles, as God granted humans with the power to overcome them (Quraish Shihab in Rahiem et al., 2017). There will be reward after hardship (Komaruddin Hidayat in ibid), so then humans should surrender to their fate according to this belief ('Aidh ibn Abdullah al-Qarni in ibid).

To teach children to see optimistically that there is hope after adversity and to accept the faith, is one way to teach children to be more resilient. Research has shown that faith could be a method that can be relied upon by individuals to gain control of their lives in the midst of difficult times, it is also important in mental health recovery and empowerment (YangarberHicks, 2004). Health and faith have often been viewed as separate entities with little in common, but lately there has been a significant change, with a surge of interest in conferences and journals and popular media that look at the relationship between religious faith and health (Plante and Sherman, 2001).

The participants of the study also emphasized the importance of being grateful to God for whatever happened, good or bad. Even though they may not always consistently accept it, as there are times they find it difficult. E talked about it during her interview, explaining how the questions to God concerning why it had happened came to her mind, but she was always 
able to get herself back to remain thinking positively.

It is mixed feelings, I sometimes feel grateful, but sometimes not. I sometimes have envy with those who have a perfect family. Why should this happen to me, again and again? I have lost my mother, my body is not healthy, why is it always me? But, I know there is wisdom in every difficult time. I scream alone, I sometimes cannot handle it any longer. I think I can't do this anymore. I lost my trust in God and am being ungrateful, but then I become positive again, to think there should be good things that will happen. There are people who have a more miserable life than mine. (E/Interview)

Von Vocano and Schwarz (2014) explained how religion often becomes a place to return for many believers; they looked at the teachings of religion in understanding tragic events. Some conventional disaster and coping theories neglect the role of religion, but it is something that should not be obviated, as many people derive meanings of life, in good and bad situations, from religious cosmologies, where God, the divine, is their outlet for peace and provides someone to talk to.

Another belief that showed that their religious faith keeps them staying positive and full of hope, is that they believe those who died because of the disaster are martyrs and will be granted heaven in the afterlife. E shared her experience of how she understands that her mother is now in peace and will go to heaven.

There were many people who came to our relocation camp. They were mostly from Jakarta, but even foreigners came and supported us, they told us to continue our lives full of spirit. Then, I finally accepted it. Moreover, they told us that, those who had died in the water were martyrs, they would go directly to heaven. (E/Interview)

Furthermore, E said that knowing her mom had died as a martyr and will not get punishment in her grave, helped to calm her down. She believes that her mom had a beautiful end and she even thought that not everyone will have as beautiful an end to their lives as her mother. She accepted her mom's fate and also her own fate.

Well, when I heard that my mother was a martyr, she will not get punishment in her grave, God will help her, even later at the end of the world, we will all rise up. In her grave, there is help for her, she is free from any punishments. I accepted it. I could be sincere and accept that my mother had died. She was a martyr. It calmed me down. So, I accepted that mum had died and I would not get jealous anymore, when I saw my friends with their mother. Sometimes, I felt so sad when I saw my friends were dropped and picked up from school by their parents, their mom and dad. I walked alone. But, my mother had a beautiful end, as a martyr. Not everybody gets the chance to die as a martyr. (E/Interview)

Pargament et al. (1988) explained that for the believers, their religious beliefs and practices often become their guide to understand and solve problems. These child survivors could make peace with their fate and remain positive due to the hope that those who died are actually in a better condition now. They also believe that behind every event, and even after disaster, there is wisdom and hope.

E said that she strongly believes there is wisdom and lessons behind everything. The tsunami has made her a better stronger person. She is becoming more independent and grateful with her life. 
Now, I should work very hard and support my own life. Even when I am sick, I should go to the hospital by myself, without my mother, everything I should do by myself. If I want to buy a mobile phone, I should work to get the money, so I can buy it if I have money, if I don't have the money, it means I cannot buy the phone. So, I become more independent, more grateful. At least, I could support my own life. If my mother was still alive, I may never give thanks to God for whatever he bestows to me. However, if we see the future of Aceh, how our lives are here; after the tsunami there is more destruction, moral failure. (E/Interview)

This quote also highlights how E, who lost her mom and siblings, has struggled to stay healthy after the tsunami, and is not always in a good emotional condition; she sometimes loses faith. But, despite this, she always tries to return to being positive again. This helps her to be more optimistic towards her life.

How do I feel in difficult situations? It is mixed feelings, I sometimes feel grateful, but sometimes not. I am sometimes envious with those who have a perfect family. Why has this happened to me, again and again? I have lost my mother, my body is not healthy, why is it always me? But, I know there is wisdom in every difficult time. I scream alone, I sometimes cannot handle it any longer. I think I can't do this anymore. I lost my trust in God and am being ungrateful, but then I become positive again, to think there should be good things that will happen. There are people who have a more miserable life than mine. (E/Interview)

$\mathrm{C}$ explained that she remains positive and believes that she has learned from the tragedy. She feels she has becomes less dependent and is able to be more responsible with her own life.
What makes me calm? Usually when I am sad, hmmm... when sad, hmmm, maybe take the lesson only. If I still have parents, maybe I will not be like this. Maybe, I used to be a spoiled child, who did not know anything, never did anything for myself even. I was not able to manage myself, let alone someone else's life. Now I can be independent, and can stand alone, can manage everything. Maybe that's the wisdom that can be taken. (C/Interview)

$C$ said that the tsunami had changed her from a stubborn and disobedient child into a better person. The loss of her parents helped improve her character and she now has qualities that maybe many children of a similar age do not have.

I will not be like this. Because I used to be a spoiled, stubborn person, a child who might be against her parents, who does not listen. Maybe if I still had parents I would still have such a character, still be spoiled, hmmm... still have bad qualities that I could not get rid of. Now that I do not have any parents, I do not know who I can depend on. I now believe that I needed to change for the better. (C/Interview)

A male participant, $F$, who at the time of tsunami was only 11 years old, lost his parents and three sisters, but survived with two brothers. $\mathrm{F}$ also agreed with the female participants, $\mathrm{E}$ and C, who said they believed that there was wisdom behind the tragedy. F said, "There is wisdom behind this tragedy. For me, I could live more independently. If my parents are still alive, I will not work like this (guard), maybe my life is better than this, but maybe it is worse, I need to accept the path of my life that has been written by God. He has already planned our life, the wealth, spouses, death, we only need to walk on the path." (F/Interview) 
G survived the tragedy with only one older sister remaining from his family. He explained about the positive light of the tragedy. He believes there is wisdom behind the tragedy, for example in the community's prosperity and use of technology in the village. "In my opinion, the wisdom behind this tragedy is, we did not know a lot about technology. In the villages, before the tsunami came, we had very small incomes, but after the tsunami, we have a higher income and more advanced technology." (G/Interview)

$G$ also explained how often kids overcame their sadness by playing to stay busy. They were being entertained. Sadness usually occurred during the Eid religious holiday. They would often remember how all their family used to gather on that special day. "Kids were not, well not that sad. We were busy playing. Maybe this is the wisdom, behind this disaster, there is wisdom, well kids they need entertainment. They remembered their parents, especially on the main Eid day to mark the end of the holiday, they would remember gathering with their parents before. For example, Nursalim. He would become so sad. (G/Interview)

$\mathrm{H}$, who lost both parents, advised those who still have parents to obey and treat their parents well. He said he is not able to do that anymore as they have been taken from him. "Those who still have parents, they need to obey their parents, I couldn't bring joy to my parents anymore, I try to bring joy to those people who have essentially replaced my parents; my aunty and uncle, I should make them happy, I can only visit my parents' grave now, that's it." (H/Interview)

\section{Prayer is a Source of Peace and Strength}

Recent research, highlighted that religion relates to a person's mental and physical health. Religion for many people is a form of power and a place to turn to when looking for support when things are going bad; in disaster periods, especially in post-disaster mental health support programs, the role of religion shouldn't be neglected in the process of recovery (Von Vocano and Schwarz, 2014).

How people interpret a traumatic event through a religious perspective creates a considerable impact upon the way a community recovers and mitigates (Rahiem et al., 2017). Trauma may affect the way people see their religion or God, they may question their belief or even lose faith, but in other times they may get closer to their God (McGeehan, 2012). To look at religion as a possible source of coping in post-disaster time, could be a way to prepare a community to be more resilient. This replicates what the participants in this research discussed in that they held on to their faith during and after the disaster.

The child survivors talked about how they turned to religion in difficult times and found peace in praying. Iqbal said that after the tsunami, all the survivors from his village gathered in an elementary school building that was located not far from the village, but on higher ground. There were not a lot of activities they could do, although I explained that they often prayed and slept.

There was nothing much to do, we could only pray, so we did that five times a day; praying to remember God and then sleeping. Just sleeping for a while, then being awoken due to the aftershocks that were still frequent at that time. Most of the other daily activities were just seeing those that had returned to the village looking for their loved ones (I/Interview)

$\mathrm{C}$ also mentioned the same things, how they occupied their days and thoughts with praying. "What else could be done besides just praying? What else can be given to them? Yes, I hope that they can be calm and peaceful there, that's it (C/Interview). C thought the only gift she could present to her dead parents was praying. E, F, J 
and other participants also talked about similar things. They communicated to God and to their lost family through praying. They explained that after the tsunami everything was destroyed, so the only hope they could cling on to was God. Believing their lost ones were waiting for them in heaven, enabled them to have peace with their fate, E said.

F said, he did not always pray, but whenever he was sad, he would take ablution and pray, and through this he found peace. "I don't pray always, sometimes I am lazy, sometimes forget, but I will take ablution, hmmm then pray whenever I remember them, pray for them and for myself, hoping we will gather one day in a better place." (F/Interview).

$\mathrm{H}$ said, he always misses his family most during the Eid holiday. As he cannot gather with them now, he visits their graves and prays there. $\mathrm{J}$ and $\mathrm{K}$ also visit their parents and siblings' graves during the Eid holiday. K said, "I feel like I talk with them and God. I ask forgiveness for them and myself. Please God gather us in your heaven." (K/Interview). L prayed, "Please God don't leave us alone." (L/Interview).

$\mathrm{H}$ who lost both parents, one younger brother and two sisters, found praying was a way to make him feel relief and eased his pain. "Whenever I am sad, I pray. I need to lift the weight from my chest, pray for them, to ensure they are comfortable in the grave and gain forgiveness from God." (H/Interview). Muslims believe that prayers from a direct family member, especially a child to the parent, will make their waiting time in their grave more comfortable, before they rise up to heaven.

\section{Religious Leaders/Clerics have a Significant Role in the Recovery Process}

As recorded in history, religion and healing have been used closely together for a long time. Kuhn, 1988 (as cited in Plante and Sherman,
2001) explained that, in Western culture, the first known medical license was issued for the first time by the church in the $12^{\text {th }}$ century. Due to the progress of science, the links between the two were then eroded over time, as the mind and body were viewed as fundamentally separated. In their book (ibid) Plante and Sherman questioned, "Is it possible that religious faith is among the tapestry of psychosocial factors that influence health and morbidity?" Included here is the issue of mental health.

Some literature reviews point out that the concept of a collaboration between the clergy and mental health professionals during and after a catastrophe is still debatable (Bland, 2005; Bledsoe et al., 2013). However, the efficacy of that kind of partnership has been examined in some international research. Bradfield et al. (1989) who studied the collaborative works of clergy and mental health professionals after the November 1985 West Virginia flood, stressed in their research of finding the importance of maintaining hope for the victims of natural disasters; this is not easy for them as they themselves might also be the victims of the disaster. The clergy has a role in maintaining hope of the disaster victims. "When Spirituality is affirmed in counselling, clients are empowered to draw their spiritual resources to regain hope and reconnect." (McCombs, 2010, p. 131).

Hirono and Blake (2017) conducted research on, "The Role of Religious Leaders in the Restoration of Hope Following Natural Disasters." They brought up the issue of how the role of the clergy is not recognized by mental health professionals like social workers and counsellors. They studied the American and Japanese clergies' perception of their role in natural-disaster-related PTSD relief efforts. They found some cultural differences between the Christian communities in American and Buddhist communities in Japan: a) American Christian clergies believed that they had an 
obligation in natural disaster relief efforts and they also thought that counselling with pastors can help the natural disaster victims; b) American clergies focused more on "comfort," "reducing pain," and "hope", while Japanese Buddhist clergies focused more on "listening" and "praying" anytime they had the chance to talk with family members, who had lost their loved ones. Out of the differences, both clergies said that they preferred to listen while the disaster victims talked; the clergies prayed for the victims to help them in any way possible; they tended not to focus on the negative, with the victims suggested to keep the memory of the lost loved ones in their heart. In the conclusion of the research, Hiroko and Blake (ibid) suggested, in providing both material and emotional/spiritual support to disaster victims it is important to collaborate the ideas of both mental health professionals and religious leaders.

Gianisa (2017) researched how religious faith benefitted the recovery of the disaster victims. She interviewed religious followers and leaders. She discovered that religious beliefs and practices bond local people together and contributed to a successful coping mechanism in disaster; and religious communities can fill response and recovery gaps, especially when external intervention is limited.

There are five important factors that should be promoted in post disaster practice: a sense of safety, calming, self and community efficacy, social connectedness and hope (Benedek and Fullerton, 2007). The collaboration of mental health professionals and religious clergy will be meaningful and essential in ensuring those five elements.

In our interviews, the participants mentioned about the visits of the Muslim clerics; what they did and how they appreciated the visits. E said there were many Muslim clerics who came to the temporary shelters, the camp. The clerics lead the Quran recitals, helped teach some Islamic ideas and discussed them with the people. E remembered their talks that explained how those who died due to the tsunami died as martyrs and that helped her to accept the fate and have hope.

At that time, there were many Muslim clerics who came to our camp, we read the Quran together, listened to Islamic teachings, discussed some issues. They told us that those who had died in the water are martyrs, those who died in flames are martyrs, and those who died defending their religion are martyrs. They were Muslim clerics, teachers, and scholars. (E/Interview)

E highlighted that although many people came to the camp, she felt the greatest support from the clerics, who had motivated them to keep optimistic and go on with their lives.

Yeah, there were many, for examples: reciting the Quran, motivation sessions, games, there were many activities in the relocation camp. Those activities were very helpful. Many of us lost hope, could not go on with our lives, they gave us motivation. There were aid workers who came to the camp bringing puppets; they told stories using those puppets. They brought our lives back, we became more motivated, and we wanted to go on with our lives. They were very helpful. There were some of them who were not Muslims, they supported us, and they attended our Quran recital sessions. We had some Muslim clerics, who motivated us also to go on with our lives. (E/Interview)

I said that he spent most of the time at the temporary shelter (school building), in the first month after the tsunami, playing with his friends, sleeping, and praying. "What else can we do? Hmm some of us walked to the village looking for the families, kids stayed playing, we 
slept, and prayed. Prayed five times and also recited the Quran.”

As discussed above, the child survivors were looking for peace and got hope from their faith. To understand that the lost ones are waiting for them in heaven, died as martyrs, gives them hope and made them more optimistic about their lives. $M$ said that since the tsunami he had not talked with a counsellor or psychologist. He said he usually talked with the ustadz (Muslim teachers/clerics) and that helped. "Hmm I didn't talk with anyone about my feelings... psychologist? Counsellor? None of them. The ustadz talked to us about fate, to accept and there is wisdom from God. Not about how I feel." (M/interview).

$\mathrm{L}$ said that it was important to have someone who knows Islam and can counsel them with hope, "It is good to have the ustadz to talk with us, recite the Quran and pray together. $\mathrm{He}$ reminds us about the afterlife. Those who died in water are martyrs."

\section{To Empower Women in Emergency Situations}

The death toll of the 2004 Aceh tsunami reached 220,172 in Indonesia alone (National Movement on Disaster Responses, 2005). There is no reported data though, about the proportion of male and female victims, but the report stated that most of the victims were women and children. The World Health Organization (2018) reported that women and children are often the most affected by disasters. It is believed that seventy percent of displaced persons are women and children; women are especially vulnerable for health reasons, including reproductive and sexual health problems and possible increased rates of sexual and domestic violence after the disaster; gender roles also dictate women become the primary caretakers for those who survived, especially children (ibid).
During the interview, one of the factors that the participants talked about was how some women had died because they stayed where they were when the water hit. N, who lost her mother and grandmother, told us, "The water is rising! I heard people scream and run. I said to my mom, let's go mom. Yet, my mom and my grandmother, with some other women from the neighbourhood made a circle and started to read the Quran. Scared, I ran.” (N/Interview).

A similar story was told by $\mathrm{E}$, who ran with her uncle, while others stayed and read the Quran:

Then, someone passed our house and told us to run, the wave was so high, he told us. We still stayed at home. My uncle and I just stood in front of our house, watching people frantically running in every direction. My uncle and I stayed. My mother and some other family members went out and made a circle and started to read the Quran, Yasin (the letter in the Quran that people read in bad, sad times or if someone has died). They had surrendered to God. I saw my little sister was among them also. My uncle and I stayed in front of the house, when both of us saw how high the water was, then we ran, but we were right away swallowed up, swirling in the water. (E/Interview)

$O$ said that when the situation became so chaotic and people ran away, her mom and some other women, sat together and started to pray. “Let's pray, nothing can save us except God. I remember my mom told me that. However, I ran away following my cousin."

$M$ said, that his mom was waiting for his dad, she asked him to run. "My mom told me run M. I am waiting for your dad. She was holding his three year old sister. Your dad told me if anything happened, he will come home and we will go together (M/Interview)." In 
Islam, many people believe you need a permit from your husband or father to leave the house. So, some women stayed at home because of this reason. P explained, "People started to run, I dragged my mom, let's go mom, she told me you go first, I am afraid your dad will look for me if I am not here." (P/Interview).

\section{Conclusion}

The purpose of this paper is to contribute to the discussion on the role of religious beliefs and practices in disaster mental health recovery, through collecting data from the child survivors of the 2004 tsunami in Aceh as the case study. The limitation of this study is the research findings couldn't be use as conclusion or generalization for broad communities since this research is using qualitative inquiry with limited participants.

The findings show the survivors hold on to their faith in the difficult times after the disaster. They remain optimistic about their life by accepting what happened as their fate, understanding that there is wisdom behind it, and finding peace and strength from praying. They also emphasized the importance of religious clerics in their recovery, as a trustable person to discuss the disaster. They pointed out one of the religious practices, which kept women from leaving their homes at the time of the tsunami, as they believed they should get a permit from their husband to leave the house and also they believed that only God could save them, so they did not run away at the time of tsunami. The child survivors interviewed were very young, around the age of 9-12 years old at the time of tsunami. It is amazing how, even at that young age, they can have such a deep held faith in their religion.

As discussed, religion often brings hope at the time of a disaster. The data from our research also showed how the child survivors could go on with their lives with the hope they got from their faith. As young children, they mentioned they knew this from a young age; their parents had taught them and they also they learned it from school. Religious beliefs and practices could be integrated with the disaster recovery program and also it could be used to build more resilient communities. School, through the Islamic education lessons, could introduce values that are needed to build these resilient communities. Faith was shown to be very close to the lives of the people in the Muslim communities in Aceh. The survivors saw the disaster through the perspectives of religion. Therefore, researcher sees a great opportunity for Islamic education to ensure children have a positive outlook towards disaster and to enable them to regain control of their lives by being more optimistic and see the promise of God's power to be more resilient. Islamic education should not only teach dogmas and other ideas that are actually far removed from the lives of everyday people. Islamic education needs to teach values that highlight the human personal ability and the connection to God to negotiate the adversities, to be more resilient and to use the source of power and belief within ourselves during difficult times.

\section{References}

Ali, M.D. (1995). Lembaga-Lembaga Islam di Indonesia. Jakarta: PT. Raja Grafindo Persada.

American Psychology Association https://www.apa.org/helpcenter/roadresilience Retrieved 24 December 2018

Bawani, I. (1993). Tradisionalisme dalam Pendidikan Islam. Surabaya: Al-Ikhlas.

Benedek, D., \& Fullerton, C. (2007). Translating five essential elements into programs and practice. Psychiatry: Interpersonal and Biological Processes, 70, 345-349. 
Bland, D. (2005). Psychology-church collaboration: Finding a new level of mutual participation. In M. R. McMinn \& A.W. Dominguez (Eds.), Psychology and the church (pp. 33-39). Hauppauge, NY: Nova Science Publishers.

Bledsoe, T., Setterlund, K., Adams, C., Fok-Trela, A., \& Connolly, M. (2013). Addressing pastoral knowledge and attitudes about clergy/mental health practitioner collaboration. Social Work \& Christianity, 40(1), 23-45.

Bradfield, C., Wylie, M., \& Echterling, L. G. (1989). After the flood: The response of ministers to a natural disaster. Sociological Analysis, 49, $397-$ 407.

Briggs, B. (2017). Horror and Hope: 2017 for Millions of Children Hit by Conflicts and Disasters. https://theirworld.org/news/2017review-education-children-emergenciesconflicts-disasters-refugees.

Codreanu T. A., Celenza A., \& Jacobs I. (2014). Does disaster education of teenagers translate into better survival knowledge, knowledge of skills, and adaptive behavioral change? A systematic literature review. Prehospital and Disaster Medicine, 29(6), 1-3.

Coffman, S (1994). Children Describe Life After Hurricane Andrew. Pediatric Nursing. Vol. 20: 363-368.

Dyregrov A, Yule W, Olff M. (2018) Children and natural disasters. European Journal of Psychotraumatology.

Doi:10.1080/20008198.2018.1500823.

Gianisa, A., \& Loic Le De (2018). The role of religious beliefs and practices in disaster: The case study of 2009 earthquake in Padang city, Indonesia. Disaster Prevention and Management, Vol. 27 Issue: 1, pp.7486, https://doi.org/10.1108/DPM-10-20170238
Hirono, T., \& Blake, M. E. (2017). The Role of Religious Leaders in the Restoration of Hope Following Natural Disasters. SAGE Open. https://doi.org/10.1177/21582440177 07003

Kar N. (2009, February). Psychological impact of disasters on children: Review of assessment and interventions. World Journal of Pediatrics, 5(1), 5-11. Epub 2009 Jan 27. [PubMed]

McCombs, H. (2010). The spiritual dimensions of caring for people affected by disasters. In dassbrailsford (Ed.), Crisis and disas- ter counseling: Lessons learned from Hurricane Katrina and other disasters (pp. 131-147). Thousand Oaks, CA: Sage.

PDSPK Kemdikbud Statistik Pendidikan Anak Usia Dini 2016/2017

Peek, Lori (2008). Children and Disasters: Understanding Vulnerability, Developing Capacities, and Promoting Resilience-An Introduction. Children, Youth and Environments. Vol. 18 (1): 1-29

Philipsborn R. P., \& Chan K. (2018). Climate change and global child health. Pediatrics, 141, e20173774.

Plante, T.G., \& A.C. Sherman (2001). Faith and Health: Psychological Perspectives. New York: Guilford Press.

Psychology Today https://www.psychologytoday .com/us/basics/resilience Retrieved 28 December 2018

Rahim, H. (2001). Arah Baru Pendidikan Islam di Indonesia. Ciputat: Logos

Rahim, H., \& M.D.H. Rahiem (2012). The Use of Stories as Moral Education for Young Children. International Journal of Social Science and Humanity. Vol. 2 (6): 454-458. 
Rahiem, M.D.H., N.S.M. Abdullah, \& S.E. Krauss (2017). Religious Interpretations and Psycholohical Recovery from the Aceh 2004 Tsunami: The Promise of Heaven, Healing the Trauma. In R. Djalante, M. Garschagen, F. Thomalla, \& R. Shaw (Eds.). Disaster Risk Reduction in Indonesia: Progress, Challenges, and Issues (pp. 495-514).

Rahiem, M.D.H., S.E. Krauss, \& H. Rahim (2018). The Child Victims of the Aceh Tsunami: Stories of Resilience, Coping and Moving on with Life. Procedia Engineering. Vol. 212: 1303-1310.

https://doi.org/10.1016/j.proeng.2018.01.168

Silverman, W. K., \& La Greca, A. M. (2002). Children experiencing disasters: Definitions, reactions, and predictors of outcomes. In A. M. La Greca, W. K. Silverman, E. M. Vernberg, \& M. C. Roberts (Eds.), Helping children cope with disasters and terrorism (pp. 11-33). Washington, DC, US: American Psychological

Association. http://dx.doi.org/10.1037/10454001

Southwick, M., S. Bonanno, G.S S Masten, A. Panter-Brick, C., \& R. Yehuda (2014). Resilience definitions, theory, and challenges: Interdisciplinary perspectives. European journal of psychotraumatology. 5. 10.3402/ejpt.v5.25338.
The Editors of Encyclopaedia Britannica. Indian Ocean Tsunami 2004. https://www.britannica.com/event/IndianOcean-tsunami-of-2004. Retrieved October 17,2018

Vogel, J.M., \& E.M. Vernberg (1993). Children's Psychological Responses to Disaster. Journal of Clinical Child Psychology. Vol. 22: 464-484

World Health Organization (2018) Gender and Disaster.

http://www.searo.who.int/entity/gender/topics /disaster_women/en/ retrieved November $16^{\text {th }}$ 2018

Yangarber-Hicks, N. (2004). Religious Coping Styles and Recovery from Serious Mental Illnesses. Journal of Psychology and Theology, 32(4), 305317. https://doi.org/10.1177/0091647104032 00403. 